\title{
Article \\ The Relationship between Antibiotic Susceptibility and pH in the Case of Uropathogenic Bacteria
}

\author{
Annamária Kincses (D), Bálint Rácz, Zain Baaity (D), Orsolya Vásárhelyi, Erzsébet Kristóf, Ferenc Somogyvári * (D) and \\ Gabriella Spengler *(D)
}

check for

updates

Citation: Kincses, A.; Rácz, B.; Baaity,

Z.; Vásárhelyi, O.; Kristóf, E.;

Somogyvári, F.; Spengler, G. The

Relationship between Antibiotic

Susceptibility and $\mathrm{pH}$ in the Case of

Uropathogenic Bacteria. Antibiotics

2021, 10, 1431. https://doi.org/

10.3390/antibiotics10121431

Academic Editor: Khondaker Miraz

Rahman

Received: 30 September 2021

Accepted: 20 November 2021

Published: 23 November 2021

Publisher's Note: MDPI stays neutral with regard to jurisdictional claims in published maps and institutional affiliations.

Copyright: (c) 2021 by the authors. Licensee MDPI, Basel, Switzerland. This article is an open access article distributed under the terms and conditions of the Creative Commons Attribution (CC BY) license (https:/ / creativecommons.org/licenses/by/ $4.0 /)$.
Albert Szent-Györgyi Health Center, Department of Medical Microbiology, Albert Szent-Györgyi Medical School, University of Szeged, Semmelweis utca 6, 6725 Szeged, Hungary; kincses.annamaria90@gmail.com (A.K.); racz.balint@med.u-szeged.hu (B.R.); baaity.zain@med.u-szeged.hu (Z.B.); orsolya.vasarhelyi.91@gmail.com (O.V.); krstf.erzsebet@gmail.com (E.K.)

* Correspondence: somogyvari.ferenc@med.u-szeged.hu (F.S.); spengler.gabriella@med.u-szeged.hu (G.S.); Tel.: +36-62-545-115 (F.S. \& G.S.)

\begin{abstract}
Urinary tract infections (UTIs) are common bacterial infections caused mainly by enteric bacteria. Numerous virulence factors assist bacteria in the colonization of the bladder. Bacterial efflux pumps also contribute to bacterial communication and to biofilm formation. In this study, the phenotypic and genetic antibiotic resistance of clinical UTI pathogens such as Escherichia coli, Klebsiella pneumoniae, and Proteus mirabilis were determined by disk diffusion method and polymerase chain reaction (PCR). Following this, different classes of antibiotics were evaluated for their antibacterial activity at $\mathrm{pH}$ 5, 6, 7 and 8 by a microdilution method. Gentamicin (GEN) was the most potent antibacterial agent against $E$. coli strains. The effect of GEN on the relative expression of marR and sdiA genes was evaluated by quantitative PCR. The slightly acidic $\mathrm{pH}(\mathrm{pH}$ 6) and GEN treatment induced the upregulation of marR antibiotic resistance and sdiA QS activator genes in both E. coli strains. Consequently, bacteria had become more susceptible to GEN. It can be concluded that antibiotic activity is $\mathrm{pH}$ dependent and so the artificial manipulation of urinary $\mathrm{pH}$ can contribute to a more effective therapy of multidrug resistant bacterial infections.
\end{abstract}

Keywords: urinary tract infection (UTI); multidrug resistance; quorum sensing; efflux pump; biofilm; $\mathrm{pH}$ dependence

\section{Introduction}

Urinary tract infections (UTIs) are one of the most frequently encountered bacterial infections in everyday health care. There are various classifications of UTIs: lower (limited to the bladder) or upper (pyelonephritis), complicated (in patients with a catheter, structural or functional abnormality or pregnant), or uncomplicated (none of the above). The diagnosis depends on the urinary symptoms and on the urine culture positive for an uropathogen exceeding a given threshold (which varies according to gender and the presence of a urinary catheter). Both patient and bacterial factors contribute to the development of UTIs. Anatomical or functional abnormalities, genetic predisposition, and certain behaviors (e.g., sexual intercourse) can increase susceptibility to uropathogens [1]. Several virulence factors aid the bacteria in the colonization of the bladder and the evasion of the immune system. These include the urease enzyme, adhesins, biofilm formation, toxins, and iron acquisition systems [2].

The dominant bacterial species involved in uncomplicated and complicated UTIs is uropathogenic Escherichia coli (UPEC). Other species include Klebsiella pneumoniae, Staphylococcus saprophyticus, Enterococcus faecalis, group B Streptococcus (GBS), Proteus mirabilis, Pseudomonas aeruginosa, Staphylococcus aureus, and Candida spp. [3]. Commonly used antibiotics for treating UTIs are trimethoprim sulfamethoxazole, third generation cephalosporins, ciprofloxacin, and ampicillin. However, as a result of emerging multidrug resistance, 
antibiotic treatment is becoming more difficult. This is more pronounced in the case of the Enterobacteriaceae family, which has resistance to third-generation cephalosporines and other antibiotics [4] through its production of extended spectrum $\beta$-lactamases (ESBL), class C $\beta$-lactamases (AmpC enzymes) and carbapenemases.

Emerging multidrug resistance and the high recurrence rate of UTIs pose a significant threat, particularly to women, infant boys, and older men. The use of prophylactic antibiotics is no longer sustainable. However, vaccine therapies and anti-virulence factor therapies could be promising strategies [5]. Another attractive approach to battle multidrug resistance is single-dose aminoglycoside therapy, saving carbapenems for treatment of severe infections. Aminoglycosides are excreted in high concentrations in urine and, with a single parenteral dose, patient non-adherence can be avoided [6,7].

Urinary $\mathrm{pH}$ levels vary broadly $(\mathrm{pH} 4.5-8)$ and can be easily modified by diet or medications. Modification of the urinary $\mathrm{pH}$ could play an important role both in the treatment and in the prevention of UTIs, since $\mathrm{pH}$ is an essential factor in the colonization and proliferation of uropathogenic bacteria and modifies the efficacy of antibiotics [8-10]. Siderocalin (SCN), a lipocain-type molecule produced also by uroepithelial cells, has a key function in the host defense system. It binds iron-binding siderophores (for example, enterobactin) released by microorganisms, however SCN activity levels can be influenced by $\mathrm{pH}$ and metabolites [11].

Quorum sensing (QS) is a cell-cell communication system which regulates gene expression based on population density. It enables bacteria to form biofilms and express various virulence factors, which can contribute to increased drug resistance [12]. QS is also involved in the pathogenesis of UTIs, especially catheter-associated urinary tract infections (CAUTIs). It regulates motility and biofilm formation, allowing the colonization of the bladder [13]. Urine composition is a crucial host factor that can alter the risk of a UTI; a $\mathrm{pH}$ less than 5, organic acids, and high urea content make the environment less ideal for bacterial growth. Moreover, urea in the urine is also able to inhibit the expression of QS related genes [14]. Efflux pumps (EPs) are membrane proteins that are mostly associated with antibiotic resistance, however they may also have a major role in the formation of biofilm and in QS regulation. EPs may take part in the efflux of antibiotics and metabolic intermediates, along with extracellular polymeric substances and QS molecules. They can influence aggregation and indirectly regulate biofilm-associated genes. Therefore, the development of molecules with efflux pump inhibitory activity may appeal in order to reverse multidrug resistance in bacteria and also as anti-biofilm agents [15].

\section{Results}

\subsection{Antibiotic Susceptibility Test}

In vitro antibiotic susceptibility tests were conducted on six UTI bacterial isolates and MIC breakpoints were determined according to EUCAST guidelines [16]. Fifteen antibacterial agents were used for the susceptibility testing (cefuroxime, ceftriaxone, ceftazidime, ceftazidime/avibactam, trimethoprim/sulfamethoxazole, ertapenem, imipenem, meropenem, gentamicin, tobramycin, amikacin, ciprofloxacin, norfloxacin, ampicillin, and amoxicillin-clavulanic acid).

E. coli 32313 was susceptible to all antibiotics but resistant to trimethoprim/sulfametho xazole, gentamicin, ciprofloxacin, and norfloxacin. E. coli 33504 was completely susceptible to all antibiotics. K. pneumoniae 33443 was resistant to ampicillin, ciprofloxacin, and norfloxacin. K. pneumoniae 33163 was susceptible to ceftazidime/avibactam and intermediate for tobramycin and amikacin but was resistant to the other antibiotics. P. mirabilis 33877 was resistant to ampicillin and trimethoprim/sulfamethoxazole but was susceptible to all other tested antibiotics. P. mirabilis 32470 was susceptible to ceftazidime/avibactam and intermediate to amikacin but was resistant to the other antibiotics tested. All strains were susceptible to ertapenem, meropenem, and imipenem.

The results of phenotypic and genetic investigations are presented in Tables 1 and 2, respectively. 
Table 1. Phenotypic antibacterial susceptibility results.

\begin{tabular}{|c|c|c|c|c|c|c|c|c|c|c|c|c|}
\hline \multirow{2}{*}{$\begin{array}{l}\text { Antibiotic } \\
\text { Ampicillin }\end{array}$} & \multicolumn{2}{|c|}{ E. coli 32313} & \multicolumn{2}{|c|}{ E. coli 33504} & \multicolumn{2}{|c|}{$\begin{array}{c}\text { K. pneumoniae } \\
33443\end{array}$} & \multicolumn{2}{|c|}{$\begin{array}{c}\text { K. pneumoniae } \\
33163\end{array}$} & \multicolumn{2}{|c|}{$\begin{array}{c}\text { P. mirabilis } \\
33877\end{array}$} & \multicolumn{2}{|c|}{$\begin{array}{c}\text { P. mirabilis } \\
32470\end{array}$} \\
\hline & $22 \mathrm{~mm}$ & $\mathrm{~S}$ & $25 \mathrm{~mm}$ & $\mathrm{~S}$ & $6 \mathrm{~mm}$ & $\mathrm{R}$ & $0 \mathrm{~mm}$ & $\mathrm{R}$ & $0 \mathrm{~mm}$ & $\mathrm{R}$ & $0 \mathrm{~mm}$ & $\mathrm{R}$ \\
\hline AMC & $22 \mathrm{~mm}$ & $S$ & $25 \mathrm{~mm}$ & $S$ & $23 \mathrm{~mm}$ & $\mathrm{~S}$ & $8 \mathrm{~mm}$ & $\mathrm{R}$ & $28 \mathrm{~mm}$ & $\mathrm{~S}$ & $0 \mathrm{~mm}$ & $\mathrm{R}$ \\
\hline Cefuroxime & $22 \mathrm{~mm}$ & $S$ & $25 \mathrm{~mm}$ & $S$ & $20 \mathrm{~mm}$ & $\mathrm{~S}$ & $0 \mathrm{~mm}$ & $\mathrm{R}$ & $28 \mathrm{~mm}$ & S & $0 \mathrm{~mm}$ & $\mathrm{R}$ \\
\hline Ceftriaxone & $30 \mathrm{~mm}$ & $S$ & $34 \mathrm{~mm}$ & $S$ & $24 \mathrm{~mm}$ & S & $8 \mathrm{~mm}$ & $\mathrm{R}$ & $30 \mathrm{~mm}$ & $\mathrm{~S}$ & $15 \mathrm{~mm}$ & $\mathrm{R}$ \\
\hline Ceftazidime & $27 \mathrm{~mm}$ & $S$ & $30 \mathrm{~mm}$ & S & $24 \mathrm{~mm}$ & $S$ & $8 \mathrm{~mm}$ & $\mathrm{R}$ & $30 \mathrm{~mm}$ & $S$ & $8 \mathrm{~mm}$ & $\mathrm{R}$ \\
\hline CZA & $26 \mathrm{~mm}$ & $S$ & $28 \mathrm{~mm}$ & $S$ & $24 \mathrm{~mm}$ & $S$ & $24 \mathrm{~mm}$ & $\mathrm{~S}$ & $30 \mathrm{~mm}$ & $S$ & $28 \mathrm{~mm}$ & S \\
\hline TMP/SMX & $0 \mathrm{~mm}$ & $\mathrm{R}$ & $30 \mathrm{~mm}$ & S & $18 \mathrm{~mm}$ & S & $0 \mathrm{~mm}$ & $\mathrm{R}$ & $0 \mathrm{~mm}$ & $\mathrm{R}$ & $0 \mathrm{~mm}$ & $\mathrm{R}$ \\
\hline Ertapenem & $35 \mathrm{~mm}$ & $S$ & $35 \mathrm{~mm}$ & $S$ & $30 \mathrm{~mm}$ & S & $30 \mathrm{~mm}$ & $S$ & $30 \mathrm{~mm}$ & S & $30 \mathrm{~mm}$ & S \\
\hline Imipenem & $30 \mathrm{~mm}$ & $S$ & $30 \mathrm{~mm}$ & $S$ & $30 \mathrm{~mm}$ & $S$ & $30 \mathrm{~mm}$ & $S$ & $30 \mathrm{~mm}$ & $S$ & $30 \mathrm{~mm}$ & $S$ \\
\hline Meropenem & $30 \mathrm{~mm}$ & $S$ & $30 \mathrm{~mm}$ & S & $30 \mathrm{~mm}$ & $S$ & $30 \mathrm{~mm}$ & $\mathrm{~S}$ & $30 \mathrm{~mm}$ & S & $30 \mathrm{~mm}$ & S \\
\hline Gentamicin & $13 \mathrm{~mm}$ & $\mathrm{R}$ & $22 \mathrm{~mm}$ & $S$ & $20 \mathrm{~mm}$ & $S$ & $0 \mathrm{~mm}$ & $\mathrm{R}$ & $24 \mathrm{~mm}$ & $S$ & $15 \mathrm{~mm}$ & $\mathrm{R}$ \\
\hline Tobramycin & $20 \mathrm{~mm}$ & $\mathrm{~S}$ & $22 \mathrm{~mm}$ & $S$ & $20 \mathrm{~mm}$ & $S$ & $15 \mathrm{~mm}$ & I & $24 \mathrm{~mm}$ & S & $14 \mathrm{~mm}$ & $\mathrm{R}$ \\
\hline Amikacin & $20 \mathrm{~mm}$ & $\mathrm{~S}$ & $22 \mathrm{~mm}$ & $S$ & $20 \mathrm{~mm}$ & S & $25 \mathrm{~mm}$ & I & $24 \mathrm{~mm}$ & S & $22 \mathrm{~mm}$ & I \\
\hline Ciprofloxacin & $0 \mathrm{~mm}$ & $\mathrm{R}$ & $30 \mathrm{~mm}$ & $S$ & $16 \mathrm{~mm}$ & $\mathrm{R}$ & $0 \mathrm{~mm}$ & $\mathrm{R}$ & $35 \mathrm{~mm}$ & $S$ & $0 \mathrm{~mm}$ & $\mathrm{R}$ \\
\hline Norfloxacin & $0 \mathrm{~mm}$ & $\mathrm{R}$ & $30 \mathrm{~mm}$ & $S$ & $16 \mathrm{~mm}$ & $\mathrm{R}$ & $0 \mathrm{~mm}$ & $\mathrm{R}$ & $35 \mathrm{~mm}$ & $S$ & $0 \mathrm{~mm}$ & $\mathrm{R}$ \\
\hline
\end{tabular}

AMC: amoxicillin-clavulanic acid, TMP/SMX: Trimethoprim Sulfamethoxazole (sumetrolim), CZA: Ceftazidime/Avibactam.

Table 2. ESBL, quinolone, and sulfonamide resistance genes in UTI bacterial isolates.

\begin{tabular}{|c|c|c|c|c|c|c|c|}
\hline \multirow{2}{*}{ Resistance Type } & \multirow{2}{*}{ Gene } & \multicolumn{2}{|c|}{ Escherichia coli } & \multicolumn{2}{|c|}{ Proteus mirabilis } & \multicolumn{2}{|c|}{ Klebsiella pneumoniae } \\
\hline & & 32313 & 33504 & 32470 & 33877 & 33163 & 33443 \\
\hline \multirow{4}{*}{ ESBL } & tem & - & - & + & - & + & + \\
\hline & $\operatorname{shv}$ & - & - & + & + & - & - \\
\hline & oxa & - & - & + & - & - & - \\
\hline & $c t x-m$ & - & - & + & - & - & - \\
\hline \multirow{8}{*}{ Fluoroquinolones } & $q n r A$ & - & - & - & - & - & - \\
\hline & $q n r D$ & - & - & - & - & - & - \\
\hline & $q n r B$ & - & - & - & - & - & - \\
\hline & $q n r S$ & - & - & - & - & - & - \\
\hline & $o q x A B$ & - & - & + & + & + & + \\
\hline & $\operatorname{aac}(69)-\mathrm{Ib}-\mathrm{cr}$ & + & - & + & - & + & - \\
\hline & qерA & - & - & - & - & - & - \\
\hline & qnrC & - & - & - & - & - & - \\
\hline \multirow{3}{*}{ Resistance type } & sul1 & - & - & - & - & - & - \\
\hline & sul2 & + & - & + & + & + & + \\
\hline & sul3 & - & - & - & + & - & - \\
\hline
\end{tabular}

\subsection{Genetic Investigation}

By PCR 3 tem, 2 shv, 1 ctx-m and 1 oxa amplicons were found for ESBL screening. Furthermore, 4 oq $x A B$ and $3 a a c(69)-I b-c r$ and quinolone resistance genes were detected. In addition, 4 sul 2 and 1 sul 3 sulfonamide resistance genes were identified. The results of the genetic investigations are presented in Table 2.

\subsection{Antibacterial Activity}

After the determination of resistance genes, different classes of antibiotics, namely erythromycin (ERY), ampicillin (AMP), ciprofloxacin (CIP), and gentamicin (GEN), were evaluated for their antibacterial activity. Since urinary $\mathrm{pH}$ could have an impact on the treatment of UTIs, the activity of antibiotics at different $\mathrm{pH}$ values is a critical issue. This antibiotic evaluation was performed at $\mathrm{pH} \mathrm{5,6,7}$ and 8 by microdilution method on clinical strains of E. coli, P. mirabilis, and K. pneumoniae. The results show that ERY had no antibacterial effect at $\mathrm{pH} 5$ and 6 . At $\mathrm{pH} 7$ and 8, significant activity was observed on sensitive E. coli 33504 and K. pneumoniae 33443 strains. ERY prevented the growth of tested bacteria most effectively in alkaline environment ( $\mathrm{pH} 8$; Table 3). 
Table 3. Minimal inhibitory concentrations for erythromycin, ampicillin, ciprofloxacin and gentamicin on $E$. coli, K. pneumoniae and P. mirabilis strains.

\begin{tabular}{|c|c|c|c|c|c|c|c|c|c|c|c|c|c|c|c|c|}
\hline \multirow{3}{*}{$\operatorname{MIC}(\mu \mathrm{g} / \mathrm{mL})$} & \multicolumn{4}{|c|}{ Erythromycin } & \multicolumn{4}{|c|}{ Ampicillin } & \multicolumn{4}{|c|}{ Ciprofloxacin } & \multicolumn{4}{|c|}{ Gentamicin } \\
\hline & \multicolumn{4}{|c|}{$\mathrm{pH}$} & \multicolumn{4}{|c|}{$\mathrm{pH}$} & \multicolumn{4}{|c|}{$\mathrm{pH}$} & \multicolumn{4}{|c|}{$\mathrm{pH}$} \\
\hline & 5 & 6 & 7 & 8 & 5 & 6 & 7 & 8 & 5 & 6 & 7 & 8 & 5 & 6 & 7 & 8 \\
\hline E. coli 33504 & $>100$ & $>100$ & 12.5 & 3.125 & 12.5 & 12.5 & 12.5 & 25 & 3.125 & 0.39 & 0.05 & $<0.05$ & 25 & 6.25 & 1.56 & 0.05 \\
\hline E. coli 32313 & $>100$ & $>100$ & $>100$ & $>100$ & $>25$ & $>25$ & $>25$ & $>25$ & $>25$ & $>25$ & 25 & $>25$ & 25 & 12.5 & 1.56 & 1.56 \\
\hline K. pneumoniae 33443 & $>100$ & $>100$ & 25 & 12.5 & $>25$ & $>25$ & $>25$ & $>25$ & 25 & 6.25 & 0.78 & 0.19 & 25 & 6.25 & 0.78 & $<0.05$ \\
\hline K. pneumoniae 33163 & $>100$ & $>100$ & $>100$ & 25 & $>25$ & $>25$ & $>25$ & $>25$ & $>25$ & $>25$ & $>25$ & 12.5 & $>25$ & $>25$ & $>25$ & 12.5 \\
\hline P. mirabilis 33877 & $>100$ & $>100$ & $>100$ & 50 & $>25$ & $>25$ & $>25$ & $>25$ & 0.78 & $<0.05$ & $<0.05$ & $<0.05$ & $>25$ & $>25$ & 6.25 & 0.39 \\
\hline P. mirabilis 32470 & $>100$ & $>100$ & 100 & 25 & $>25$ & $>25$ & $>25$ & $>25$ & $>25$ & $>25$ & $>25$ & $>25$ & $>25$ & $>25$ & 12.5 & 3.125 \\
\hline
\end{tabular}

AMP had no effect on the tested strains (MIC greater than $100 \mu \mathrm{g} / \mathrm{mL}$ ) except $E$. coli 33504. Here, AMP showed potent antibacterial activity at pH 5-7 (MIC: $12.5 \mu \mathrm{g} / \mathrm{mL}$; Table 3). pH dependence was also detected for CIP on E. coli 33504, K. pneumoniae 33443, K. pneumoniae 33163 , and P. mirabilis 33877 by showing higher antibacterial activity at $\mathrm{pH} 7$ and 8 (Table 3). GEN was the most active antibiotic at alkaline $\mathrm{pH}$ of all tested strains (Table 3).

\subsection{Relative Expression of marR and sdiA Genes}

GEN was the most potent antibacterial agent against E. coli strains (33504 and 32313) and, for this reason, the effect of GEN on the relative expression of marR and sdiA genes in both $E$. coli strains was evaluated. The E. coli marR gene encodes a repressor of the marR $A B$ operon, a regulatory locus controlling multiple antibiotic resistance. In addition, sdiA encodes the transcription factor SdiA, a LuxR homolog that can respond to acylhomoserine lactone (AHL), which, in turn, is related to quorum sensing. As shown by Figures 1 and 2, GEN treatment in a pH 6 environment induced a significant stress response in both $E$. coli strains with the marR and sdiA genes being upregulated compared to the other $\mathrm{pH}$ levels. In contrast, marR and sdiA genes at $\mathrm{pH} 8$ and in the presence of GEN were downregulated in the tested strains (Figures 1 and 2).

\section{E. coli 32313}

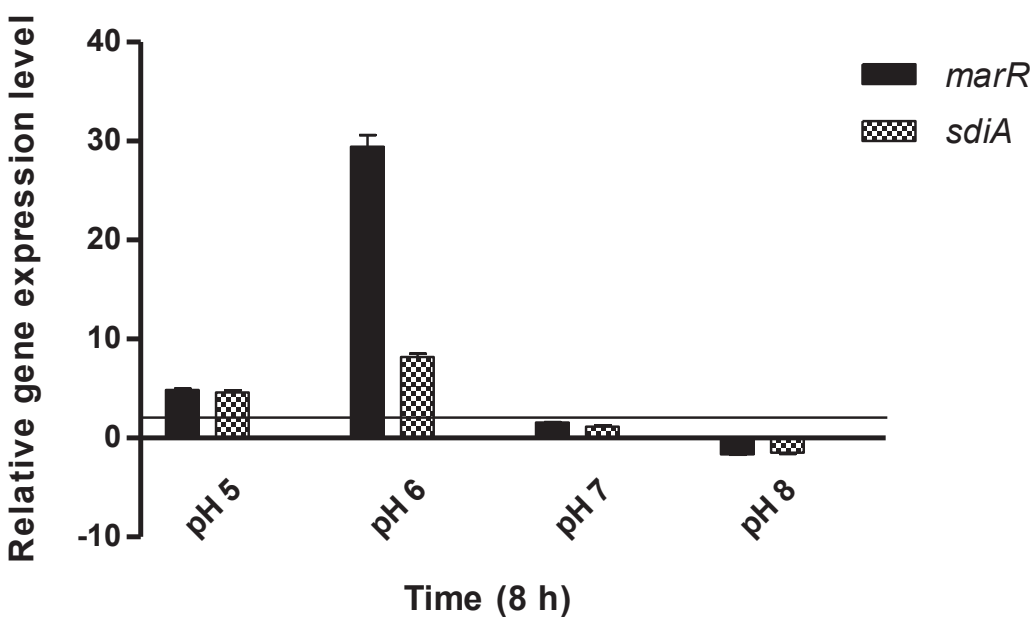

Figure 1. Relative gene expression levels of $m a r R$ and $s d i A$ genes in the presence of gentamicin in Escherichia coli 32313 after $8 \mathrm{~h}$ exposure. The line denotes the threshold value, which was set at a two-fold increase in transcripts. 


\section{E. coli 33504}

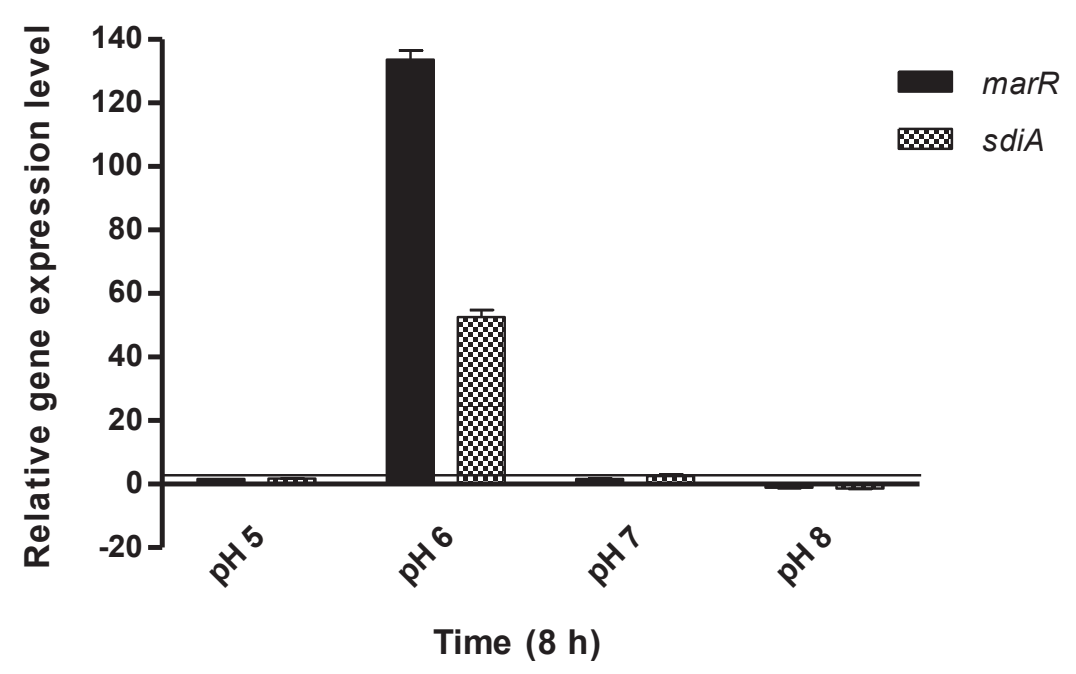

Figure 2. Relative gene expression levels of $m a r R$ and $s d i A$ genes in the presence of gentamicin in Escherichia coli 33504 after $8 \mathrm{~h}$ exposure. The line denotes the threshold value, which was set at a two-fold increase in transcripts.

\section{Discussion}

The results demonstrate that the genetic data agrees mostly with the phenotypical investigations, although there are some differences between the two methods. In E. coli 32313 clinical strain, having taken into consideration that the aac(69)-Ib-cr gene is also responsible for concurrent aminoglycoside and fluoroquinolone resistance induction [17], the genetic background of fluoroquinolone and the sulfonamide resistance agrees with the phenotype. P. mirabilis 33877 strain has one fluoroquinolone resistance gene present (oqxAB), which does not correspond to the phenotypic investigation. Finally, K. pneumoniae 33443 contained the sul2 gene, which was phenotypically inactive.

There are two possible reasons for these differences. The first possible reason is that the genetic investigation was not quantitative and there were insufficient copies of the gene. The genetic investigation could be quantified using more sensitive quantitative realtime PCR. Additionally, oq $x A B$ confers low to intermediate resistance to quinolones [16]. According to the literature, there is no complete agreement between phenotypical and genetic methods, therefore these differences could have been caused by multiple factors, for example, by the lack of promoter regions (an IS26 element in the case of oqxAB) $[18,19]$. It was demonstrated that the acidic $\mathrm{pH}$ and promethazine treatment induced a significant stress response in E. coli. Moreover, the genes $\operatorname{mar} B, \operatorname{marR}, \operatorname{acr} A, \operatorname{acr} B, \operatorname{sox} S$, ftsI and sdiA were up-regulated at an acidic $\mathrm{pH}$ compared to the treatment at a neutral $\mathrm{pH}$ [20].

In this study, the activity of the antibiotics of different classes was studied by broth microdilution method at $\mathrm{pH} 5,6,7$ and 8 on sensitive and resistant UTI bacterial strains. It can be concluded that the activity of ERY, CIP, and GEN was more effective in an alkaline environment on the tested strains. Furthermore, AMP showed a more potent efficacy at acidic and neutral $\mathrm{pH}$ levels on E. coli 33504. Urine $\mathrm{pH}$ can be modified to prevent certain urological diseases [10]. Patient urinary $\mathrm{pH}$ can be acidified by ascorbic acid and ammonium chloride while becoming more alkaline with sodium bicarbonate or potassium citrate [10]. The results confirmed that the activity of antimicrobial drugs is $\mathrm{pH}$ dependent. This enables the artificial manipulation of urinary $\mathrm{pH}$ to contribute to a more effective therapy of urinary tract infections, especially in cases of infections caused by multidrug resistant bacteria. Additionally, this technique could reduce the cost of treatment.

The slightly acidic $\mathrm{pH}(\mathrm{pH}$ ) and GEN treatment induced the upregulation of marR antibiotic resistance and sdiA QS activator genes in both E. coli strains, increasing bacterial susceptibility. A possible explanation for this could be the pH-dependent activity of siderocalin (SCN) protein, which is produced by uroepithelium. This has the ability to 
bind the iron-binding enterobactin. In a previous study, the activity of SCN increased at $\mathrm{pH}>6.45$. The elevated $\mathrm{pH}$ facilitated host-derived ferric-aryl complex assembly in SCN, leading to the iron starvation of uropathogenic E. coli (UPEC) [11]. This observation suggests that $E$. coli at $\mathrm{pH} 6$ is more susceptible to the antimicrobial agents that caused the over-expression of marR and sdiA genes. It needs to be highlighted that our study represents in vitro results lacking the response of the host to UPEC, therefore host factors should also be included in further in vivo studies.

\section{Materials and Methods}

\subsection{Bacterial Strains}

Clinical strains of Escherichia coli 33503, 32313; Klebsiella pneumoniae 33443, 33163; Proteus mirabilis 3387, 32470 were provided by the Institute of Clinical Microbiology at the University of Szeged and were included for the investigations. The species identities of the clinical isolates were confirmed by both MALDI-TOF MS and conventional biochemical methods.

\subsection{Determination of Minimum Inhibitory Concentrations by Microdilution Method}

The minimum inhibitory concentrations (MICs) of antibiotics (erythromycin (ERY), ampicillin (AMP), ciprofloxacin (CIP), and gentamicin (GEN)) were determined by microdilution method in 96-well plates according to the Clinical and Laboratory Standards Institute (CLSI) guidelines using $\mathrm{MHB}$ at $\mathrm{pH} \mathrm{5,} \mathrm{6,} 7$ and 8 [21]. The bacterial strains were separately cultured in media of $\mathrm{pH} 5$ to $\mathrm{pH} 8$ overnight at $37^{\circ} \mathrm{C}$ and the bacterial culture grown at the appropriate $\mathrm{pH}$ was applied in the assay.

\subsection{Disk Diffusion}

The antibiotic susceptibilities of clinical isolates were determined by Kirby-Bauer's disk diffusion method. Susceptibility and resistance were determined according to the Clinical and Laboratory Standards Institute criteria [21].

Briefly, a suspension of the bacteria equal to a $0.5 \mathrm{McFarland}$ standard was prepared in phosphate-buffered saline (PBS, $\mathrm{pH}$ 7.2) from an overnight culture. Using a swab, strains were inoculated onto a Mueller-Hinton agar (MHA; Bio-Rad, Hercules, CA, USA) plate.

Tested antimicrobials were ampicillin $(10 \mu \mathrm{g})$, amoxicillin-clavulanic acid $(20 / 10 \mu \mathrm{g})$, cefuroxime $(30 \mu \mathrm{g})$, ceftriaxone $(30 \mu \mathrm{g})$, ceftazidime $(10 \mu \mathrm{g})$, ceftazidime/avibactam $(30 / 20 \mu \mathrm{g})$, trimethoprim sulfamethoxazole $(1.25 / 23.75 \mu \mathrm{g})$, ertapenem $(10 \mu \mathrm{g})$, imipenem $(10 \mu \mathrm{g})$, meropenem $(10 \mu \mathrm{g})$, gentamicin $(10 \mu \mathrm{g})$, tobramycin $(10 \mu \mathrm{g})$, amikacin $(30 \mu \mathrm{g})$, ciprofloxacin $(5 \mu \mathrm{g})$, and norfloxacin $(10 \mu \mathrm{g})$. The susceptibility disks were purchased from Biolab Inc. (Budapest, Hungary). The plates were incubated for 16 to $18 \mathrm{~h}$ at $35^{\circ} \mathrm{C}$, and inhibition zones were determined visually.

\subsection{Bacterial DNA Purification}

The bacterial DNA was extracted by the QIAamp ${ }^{\circledR}$ DNA Blood Mini Kit (QIAGEN Inc, Chatsworth, CA, USA) following the manufacturer's instructions. One milliliter of logphase culture suspension, at a concentration of $10^{7} \mathrm{CFU} / \mathrm{mL}$, was used for the preparation. To trigger lysis of the bacterial cell wall, a preincubation step with $20 \mathrm{mg} / \mathrm{mL}$ lysozyme (in $20 \mathrm{mM}$ Tris $\mathrm{HCl}, \mathrm{pH}$ 8.0, $2 \mathrm{mM}$ EDTA, 1.2\% Triton X-100) was applied. The spin protocol was followed after incubation at $30^{\circ} \mathrm{C}$ for $30 \mathrm{~min}$. The final concentration of DNA was quantified using NanoDrop ${ }^{\mathrm{TM}}$ Lite spectrophotometer (Thermo Fisher Scientific ${ }^{\mathrm{TM}}$, Waltham, MA, USA) equipment. DNA samples were stored at $-20^{\circ} \mathrm{C}$ until further use.

\subsection{Gene Targets}

Three groups of antibiotic resistance genes were investigated in the genetic analysis. ESBL genes were $B l a_{\mathrm{TEM}}, B l a_{\mathrm{SHV}}, B l a_{\mathrm{OXA}}$, and $B l a_{\mathrm{CTX}} ;$ plasmid-mediated quinolone resistance genes were $q \eta r A, q \eta r D, q n r B, q n r S$, oqxAB, aac $\left(6^{\prime}\right)-I b-c r, q e p A$, and $q n r C$. Finally, sulfonamide genes were sul1, sul2, and sul3. 


\subsection{Primers}

Primer sets previously published in the literature were used with slight modification [22-25]. The written melting temperature (Tm) of the primers was $60^{\circ} \mathrm{C}$ in all cases. However, although rare, some of the primers had higher calculated melting temperatures than published. These were modified by leaving some bases on the $5^{\prime}$ end of the original sequences. Thus, the specificity was unchanged but the differences in Tm were less than $1{ }^{\circ} \mathrm{C}$. Primer sequences resulting amplicon lengths and references are listed in Tables 4-6. The published primer sequences are listed, and the modifications are underlined.

Table 4. ESBL resistance genes and primers.

\begin{tabular}{|c|c|c|c|c|}
\hline Gene & Primer & Sequence $\left(5^{\prime}-3^{\prime}\right)$ & $\begin{array}{l}\text { Amplicon Size } \\
\text { (bp) }\end{array}$ & Reference \\
\hline \multirow{2}{*}{ TEM } & $\mathrm{F}$ & CATTTCCGTGTCGCCCTTATTC & \multirow{2}{*}{800} & \multirow{6}{*}{ [22] } \\
\hline & $\mathrm{R}$ & $\overline{\text { CGTTCATCCATAGTTGCCTGAC }}$ & & \\
\hline \multirow{2}{*}{ SHV } & $\mathrm{F}$ & AGCCGCTTGAGCAAATTAA $\underline{\overline{A C}}$ & \multirow{2}{*}{713} & \\
\hline & $\mathrm{R}$ & ATCCCGCAGATAAATCACCAC & & \\
\hline \multirow{2}{*}{$O X A$} & $\mathrm{~F}$ & 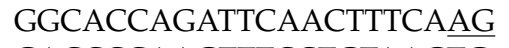 & \multirow{2}{*}{564} & \\
\hline & $\mathrm{R}$ & GACCCCAAGTTTCCTGTAAGTG & & \\
\hline \multirow{2}{*}{ CTX-M } & $\mathrm{F}$ & TTTGCGATGTGCAGTACCAGTAA & \multirow{2}{*}{544} & \multirow{2}{*}{ [23] } \\
\hline & $\mathrm{R}$ & CGATATCGTTGGTGGTGCCATA & & \\
\hline
\end{tabular}

Table 5. Plasmid-mediated quinolone resistance genes and primers [24].

\begin{tabular}{|c|c|c|c|}
\hline Gene & Primer & Sequence $\left(5^{\prime}-3^{\prime}\right)$ & Amplicon Size (bp) \\
\hline \multirow{2}{*}{$q n r A$} & $\mathrm{~F}$ & CAGCAAGAGGATTTCTCACG & \multirow[b]{2}{*}{630} \\
\hline & $\mathrm{R}$ & AATCCGGCAGCACTATTACTC & \\
\hline \multirow{3}{*}{$q n r D$} & $\mathrm{~F}$ & $\overline{\text { CGAGATCAATTTACGGGGAATA }}$ & \multirow{2}{*}{581} \\
\hline & $\mathrm{R}$ & AACAAGCTGAAGCGCCTG & \\
\hline & $\mathrm{F}$ & $\overline{\text { GGCTGTCAGTTCTATGATCG }}$ & \multirow{3}{*}{488} \\
\hline \multirow[t]{2}{*}{$q n r B$} & $\mathrm{R}$ & GAGCAACGATGCCTGGTAG & \\
\hline & $\operatorname{deg} R$ & $\overline{\text { SAKCAACGATGCCTGGTAG }}$ & \\
\hline \multirow{2}{*}{$q n r S$} & F & GCAAGTTCATTGAACAGGGT & \multirow{2}{*}{428} \\
\hline & $\mathrm{R}$ & TCTAAACCGTCGAGTTCGGCG & \\
\hline \multirow{2}{*}{$o q x A B$} & $\mathrm{~F}$ & CCGCACCGATAAATTAGTCC & \multirow[b]{2}{*}{313} \\
\hline & $\mathrm{R}$ & GGCGAGGTTTTGATAGTGGA & \\
\hline \multirow{2}{*}{$a a c\left(6^{\prime}\right)-I b-c r$} & $\mathrm{~F}$ & TTGGAAGCGGGGACGGAM & \multirow{2}{*}{260} \\
\hline & $\mathrm{R}$ & ACACGGCTGGACCATA & \\
\hline \multirow{2}{*}{ qерA } & $\mathrm{F}$ & $\underline{\text { GCAGGTCCAGCAGCGGGTAG }}$ & \multirow{2}{*}{218} \\
\hline & $\mathrm{R}$ & СTTCCTGCCCGAGTATCGTG & \\
\hline \multirow{2}{*}{$q n r C$} & $\mathrm{~F}$ & $\overline{\text { GCAGAATTCAGGGGTGTGAT }}$ & \multirow{2}{*}{118} \\
\hline & $\mathrm{R}$ & AACTGCTCCAAAAGCTGC $\overline{T C}$ & \\
\hline
\end{tabular}

Table 6. Sulfonamide resistance genes and primers [26].

\begin{tabular}{cccc}
\hline Gene & Primer & \multicolumn{1}{c}{ Sequence $\mathbf{( 5}^{\prime} \mathbf{- 3}^{\prime} \mathbf{)}$} & Amplicon Size (bp) \\
\hline \multirow{2}{*}{ sul1 } & $\mathrm{qF}$ & TGTCGAACCTTCAAAAGCTG & \multirow{2}{*}{113} \\
& $\mathrm{qR}$ & TGGACCCAGATCCTTTACAG & \\
sul2 & $\mathrm{qF}$ & ATCTGCCAAACTCGTCGTTA & \multirow{2}{*}{89} \\
& $\mathrm{qR}$ & CAATGTGATCCATGATGTCG & \\
\multirow{2}{*}{ sul3 } & $\mathrm{qF}$ & GGTTGAAGATGGAGCAGATG & 111 \\
& $\mathrm{qR}$ & GCCTTAATGACAGGTTTGAGTC & \\
\hline
\end{tabular}

\subsection{PCR Conditions}

The same conditions and equipment were used in each PCR assay. A BIO-RAD CFX 96 instrument (Bio-Rad, Hercules, CA, USA) was used for PCR reaction. Each reaction was performed in $10 \mu \mathrm{L}$ containing $5 \mu \mathrm{L}$ MMX (Fermentas Probe/ROX qPCR MasterMix, 
Fermentas, Lithuania), $1 \mu \mathrm{L}$ template DNA, $0.5 \mu \mathrm{M}$ forward and reverse primers. The PCR cycling parameters were 1 cycle at $95^{\circ} \mathrm{C}$ for $3 \mathrm{~min}, 40$ cycles denaturation $95^{\circ} \mathrm{C}$ for $15 \mathrm{~s}$, annealing at $60{ }^{\circ} \mathrm{C}$ for $20 \mathrm{~s}$ and elongation at $72{ }^{\circ} \mathrm{C}$ for $1 \mathrm{~min}$. The PCR fragments were separated by electrophoresis on $1.5 \%$ agarose gels containing GelRed Nucleic Acid Stain $(10,000 \times$ in water; Biotium Inc., Hayward, CA, USA) and visualized by UV illumination (Bio-Rad Molecular Imager ${ }^{\circledR}$ GelDoc $^{\mathrm{TM}} \mathrm{XR}+$ system with ImageLab ${ }^{\mathrm{TM}}$ Software, Bio-Rad Laboratories, Inc., Hercules, CA, USA). Data were evaluated and compared with DNA ladder 100-1000 bp (Bioline, London, UK) DNA marker.

\subsection{Bacterial RNA Purification}

E. coli 33504 and E. coli 32313 strains were cultured overnight in LB broths of $\mathrm{pH} 5$ to $\mathrm{pH}$ 8 at $37^{\circ} \mathrm{C}$ with shaking $\left(\mathrm{OD}_{600}: 0.6\right)$. Bacterial suspensions were prepared with and without GEN ( $\left.\frac{1}{2} \mathrm{MIC}\right)$ in LB medium at $\mathrm{pH} 5$ to $\mathrm{pH} 8$ and incubated at $37^{\circ} \mathrm{C}$ with shaking. The total RNA was isolated after $8 \mathrm{~h}$ of culturing. RNA preparation was carried out in an RNase-free environment using NucleoSpin RNA kit (Macherey Nagel, Germany) according to the manufacturer's instructions. Purified RNA was stored in RNase-free water in nucleasefree collection tubes and was maintained at $-20{ }^{\circ} \mathrm{C}$ until quantification was performed. The concentration of the extracted RNA templates was assessed by spectrophotometry at 260 nm (Bio-Rad, Hercules, CA, USA, SmartSpec ${ }^{\mathrm{TM}}$ Plus).

\subsection{Relative Gene Expression Analyses by Real-Time Reverse Transcriptase Quantitative Polymerase Chain Reaction (RT-qPCR)}

The relative gene expression levels were determined at $\mathrm{pH} 5$ to $\mathrm{pH} 8$ in the presence and absence of GEN. Both E. coli strains were cultured in LB at $\mathrm{pH} 5$ to $\mathrm{pH} 8$ and total RNA was isolated after $8 \mathrm{~h}$ of culturing. The relative expression levels of the marR multiple antibiotic resistance regulator and the $s d i A$ quorum sensing activator genes were determined by RT-qPCR. This involved the CFX96 Touch real-time PCR detection system (BioRad, Hercules, CA, USA), strictly following the manufacturer's recommendations for the SensiFAST ${ }^{\mathrm{TM}}$ SYBR No-ROX One-Step Kit (Bioline GmbH, Luckenwalde, Germany). Briefly, each well of the 96-well microtiter plate contained $20 \mu \mathrm{L}$ as follows: $10 \mu \mathrm{L}$ of the $2 \times$ SensiFAST ${ }^{\mathrm{TM}}$ SYBR No-ROX One-Step Mix, $0.2 \mu \mathrm{L}$ Reverse Transcriptase, $0.4 \mu \mathrm{L}$ RiboSafe RNase Inhibitor, $5.4 \mu \mathrm{L}$ Diethylpyrocarbonate (DEPC)-treated water, $500 \mathrm{nM}$ of each primer and approximately $20 \mathrm{ng}$ of total RNA in RNase-free water. Thermal cycling was initiated with a denaturation step of $5 \mathrm{~min}$ at $95^{\circ} \mathrm{C}$, followed by 40 cycles each of $10 \mathrm{~s}$ at $95^{\circ} \mathrm{C}, 30 \mathrm{~s}$ at $57{ }^{\circ} \mathrm{C}$, and $20 \mathrm{~s}$ at $72{ }^{\circ} \mathrm{C}$. The relative quantities of the mRNA of each gene of interest were determined by $\Delta \Delta C_{\mathrm{T}}$ method. Gene transcript levels were normalized against the $E$. coli housekeeping gene GAPDH measured in the same sample. The primers used in the assay shown in Table 7.

Table 7. Forward and reverse primers used for the assessment of the activity of the multiple antibiotic resistance regulator gene marR and the quorum-sensing regulator sdiA of Escherichia coli 33504 and 32313.

\begin{tabular}{cclcc}
\hline Gene & Primer & \multicolumn{1}{c}{ Sequence $\left(\mathbf{5}^{\prime} \mathbf{- 3}^{\prime} \mathbf{)}\right.$} & $\begin{array}{c}\text { Amplicon Size } \\
\mathbf{( b \mathbf { p } )}\end{array}$ & Reference \\
\hline \multirow{2}{*}{$m a r R$} & F & AGCGATCTGTTCAATGAAAT & & \\
& $\mathrm{R}$ & TTCAGTTCAACCGGAGTAAT & 170 & {$[26]$} \\
sdiA & F & CTGATGGCTCTGATGCGTTTA & 163 & \\
GAPDH & R & TCTGGTGGAAATTGACCGTATT & 170 & {$[26]$} \\
\hline
\end{tabular}

\section{Conclusions}

It is important to note that the colonization of bacteria depends on the characteristics of the population and density related virulence factors. It can be concluded that the $\mathrm{pH}$ can influence the activity of antibiotics and the function of efflux pump-related virulence 
factors such as quorum sensing and biofilm formation. Furthermore, the constituents and the $\mathrm{pH}$ of the urine can have an impact on bacterial growth. The manipulation of $\mathrm{pH}$ may increase the efficacy of antibiotics, especially in case of UTIs caused by multidrug resistant bacteria.

Author Contributions: Conceptualization, G.S. and F.S.; methodology, G.S., A.K., F.S.; data analysis, A.K., Z.B., B.R., E.K.; investigation, A.K., O.V., Z.B., B.R., E.K., G.S., F.S.; writing-original draft preparation, A.K., B.R., Z.B., F.S., G.S.; writing-review and editing, A.K., B.R., G.S.; supervision, G.S., F.S.; funding acquisition, G.S. All authors have read and agreed to the published version of the manuscript.

Funding: This research was funded by the projects SZTE ÁOK-KKA 2018/270-62-2 of the University of Szeged, Faculty of Medicine and GINOP-2.3.2-15-2016-00038 (Hungary). B.R. was supported by the project EFOP-3.6.3-VEKOP-16-2017-00009 (Hungary).

Institutional Review Board Statement: Not applicable.

Informed Consent Statement: Not applicable.

Data Availability Statement: The data presented in this study are available on request from the corresponding author.

Acknowledgments: The authors thank Edit Urbán for providing the clinical bacterial strains.

Conflicts of Interest: The authors declare no conflict of interest.

\section{References}

1. Foxman, B. The epidemiology of urinary tract infection. Nat. Rev. Urol. 2010, 7, 653-660. [CrossRef] [PubMed]

2. Kot, B. Virulence Factors and Innovative Strategies for the Treatment and Control of Uropathogenic Escherichia Coli; IntechOpen: London, UK, 2017; ISBN 978-953-51-3330-8.

3. Flores-Mireles, A.L.; Walker, J.N.; Caparon, M.G.; Hultgren, S.J. Urinary tract infections: Epidemiology, mechanisms of infection and treatment options. Nat. Rev. Microbiol. 2015, 13, 269-284. [CrossRef] [PubMed]

4. Gupta, K.; Bhadelia, N. Management of Urinary Tract Infections from Multidrug-Resistant Organisms. Infect. Dis. Clin. N. Am. 2014, 28, 49-59. [CrossRef] [PubMed]

5. O'Brien, V.P.; Hannan, T.J.; Nielsen, H.V.; Hultgren, S.J. Drug and Vaccine Development for the Treatment and Prevention of Urinary Tract Infections. Microbiol. Spectr. 2016, 4, 4. [CrossRef]

6. Poey, N.; Madhi, F.; Biscardi, S.; Béchet, S.; Cohen, R. Aminoglycosides Monotherapy as First-Line Treatment for Febrile Urinary Tract Infection in Children. Pediatr. Infect. Dis. J. 2017, 36, 1104-1107. [CrossRef]

7. Goodlet, K.J.; Benhalima, F.Z.; Nailor, M.D. A Systematic Review of Single-Dose Aminoglycoside Therapy for Urinary Tract Infection: Is It Time to Resurrect an Old Strategy? Antimicrob. Agents Chemother. 2019, 63, e02165-18. [CrossRef] [PubMed]

8. Wasfi, R.; Abdellatif, G.R.; Elshishtawy, H.M.; Ashour, H.M. First-time characterization of viable but non-culturable Proteus mirabilis: Induction and resuscitation. J. Cell. Mol. Med. 2020, 24, 2791-2801. [CrossRef]

9. Shaaban, M.; El-Rahman, O.A.A.; Al-Qaidi, B.; Ashour, H.M. Antimicrobial and Antibiofilm Activities of Probiotic Lactobacilli on Antibiotic-Resistant Proteus mirabilis. Microorganisms 2020, 8, 960. [CrossRef]

10. Yang, L.; Wang, K.; Li, H.; Denstedt, J.D.; Cadieux, P.A. The Influence of Urinary pH on Antibiotic Efficacy against Bacterial Uropathogens. Urology 2014, 84, 731.e1-731.e7. [CrossRef]

11. Shields-Cutler, R.R.; Crowley, J.R.; Hung, C.S.; Stapleton, A.E.; Aldrich, C.C.; Marschall, J.; Henderson, J.P. Human Urinary Composition Controls Antibacterial Activity of Siderocalin. J. Biol. Chem. 2015, 290, 15949-15960. [CrossRef]

12. Saxena, P.; Joshi, Y.; Rawat, K.; Bisht, R. Biofilms: Architecture, Resistance, Quorum Sensing and Control Mechanisms. Indian J. Microbiol. 2018, 59, 3-12. [CrossRef]

13. Kumar, R.; Chhibber, S.; Harjai, K. Quorum sensing is necessary for the virulence of Pseudomonas aeruginosa during urinary tract infection. Kidney Int. 2009, 76, 286-292. [CrossRef]

14. Cole, S.J.; Hall, C.L.; Schniederberend, M.; Iii, J.M.F.; Goodson, J.R.; Pesci, E.C.; Kazmierczak, B.I.; Lee, V.T. Host suppression of quorum sensing during catheter-associated urinary tract infections. Nat. Commun. 2018, 9, 4436. [CrossRef]

15. Alav, I.; Sutton, J.M.; Rahman, K.M. Role of bacterial efflux pumps in biofilm formation. J. Antimicrob. Chemother. 2018, 73, 2003-2020. [CrossRef]

16. The European Committee on Antimicrobial Susceptibility Testing. Breakpoint Tables for Interpretation of MICs and Zone Diameters. Version 7.1. 2017. Available online: http:/ / www.eucast.org (accessed on 1 September 2021).

17. Kim, Y.-T.; Jang, J.-H.; Kim, H.-C.; Kim, H.-G.; Lee, K.-R.; Park, K.-S.; Lee, H.-J.; Kim, Y.-J. Identification of strain harboring both aac $\left(6^{\prime}\right)-\mathrm{Ib}$ and aac $\left(6^{\prime}\right)$-Ib-cr variant simultaneously in Escherichia coli and Klebsiella pneumoniae. BMB Rep. 2011, 44, 262-266. [CrossRef] 
18. Li, J.; Zhang, H.; Ning, J.; Sajid, A.; Cheng, G.; Yuan, Z.; Hao, H. The nature and epidemiology of OqxAB, a multidrug efflux pump. Antimicrob. Resist. Infect. Control 2019, 8, 1-13. [CrossRef]

19. Shelburne, S.A.; Kim, J.; Munita, J.M.; Sahasrabhojane, P.; Shields, R.K.; Press, E.G.; Li, X.; Arias, C.A.; Cantarel, B.; Jiang, Y.; et al. Whole-Genome Sequencing Accurately Identifies Resistance to Extended-Spectrum $\beta$-Lactams for Major Gram-Negative Bacterial Pathogens. Clin. Infect. Dis. 2017, 65, 738-745. [CrossRef] [PubMed]

20. Nové, M.; Kincses, A.; Molnár, J.; Amaral, L.; Spengler, G. The Role of Efflux Pumps and Environmental pH in Bacterial Multidrug Resistance. In Vivo 2019, 34, 65-71. [CrossRef] [PubMed]

21. CLSI. Performance Standards for Antimicrobial Susceptibility Testing, 28th ed.; CLSI supplement M100; Clinical and Laboratory Standards Institute: Annapolis, MD, USA, 2018.

22. Dallenne, C.; Da Costa, A.; Decré, D.; Favier, C.; Arlet, G. Development of a set of multiplex PCR assays for the detection of genes encoding important $\beta$-lactamases in Enterobacteriaceae. J. Antimicrob. Chemother. 2010, 65, 490-495. [CrossRef]

23. Edelstein, M.; Pimkin, M.; Palagin, I.; Stratchounski, L. Prevalence and Molecular Epidemiology of CTX-MExtended-Spectrum $\beta$-Lactamase-Producing Escherichia coli and Klebsiella pneumoniae in Russian Hospitals. Antimicrob. Agents Chemother. 2003, 47, 3724-3732. [CrossRef] [PubMed]

24. Ciesielczuk, H.; Hornsey, M.; Choi, V.; Woodford, N.; Wareham, D. Development and evaluation of a multiplex PCR for eight plasmid-mediated quinolone-resistance determinants. J. Med. Microbiol. 2013, 62, 1823-1827. [CrossRef] [PubMed]

25. Wang, N.; Yang, X.; Jiao, S.; Zhang, J.; Ye, B.; Gao, S. Sulfonamide-Resistant Bacteria and Their Resistance Genes in Soils Fertilized with Manures from Jiangsu Province, Southeastern China. PLoS ONE 2014, 9, e112626. [CrossRef] [PubMed]

26. Viveiros, M.; Dupont, M.; Rodrigues, L.; Couto, I.; Davin-Regli, A.; Martins, M.; Pages, J.-M.; Amaral, L. Antibiotic Stress, Genetic Response and Altered Permeability of E. coli. PLoS ONE 2007, 2, e365. [CrossRef] [PubMed]

27. Kincses, A.; Szabó, Á.M.; Saijo, R.; Watanabe, G.; Kawase, M.; Molnár, J.; Spengler, G. Fluorinated Beta-diketo Phosphorus Ylides Are Novel Efflux Pump Inhibitors in Bacteria. In Vivo 2016, 30, 813-818. [CrossRef] [PubMed] 